\title{
SEMiotic Study ON “Tugu Si RaJa BataK” IN SAMOSIR ISLAND NORTH SUMATERA
}

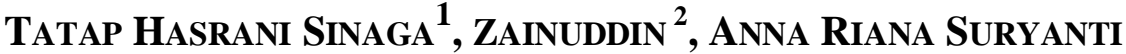 \\ TAMBUNAN $^{3}$ \\ ${ }^{123}$ UNIVERSITAS NEGERI MEDAN
}

\begin{abstract}
The objectives of this study were to find out signs, the realization of signs in to denotative and connotative meanings, and the reasons for signs realization on Tugu Si Raja Batak in Sarimarrihit Village, Sianjur Mula-Mula sub-district, Samosir Regency. The study was conducted using a qualitative approach. The data of this study were taken from Tugu Si Raja Batak. The data of the study were statues and pictures on Tugu Si Raja Batak. The data analysis was taken by observing, interviewing, and then analyzed the data based on the theory proposed by Roland Barthes. The findings indicated that there were twenty-two signs on Tugu Si Raja Batak in four forms, namely human ornaments, animal ornaments, plant ornaments, and carving. The signs of human ornaments were the Si Raja Batak means descendants with different clans and some servants for different work. The signs of animal ornaments made to show that Si Raja Batak and his descendants used the animals around him as transportations. Then, the plant ornaments they were Lime (Pangir) and Banyan tree (Jajabi) appear because the Batak people are famous for traditional medicine that uses plants such as Lime (Pangir) and betel as medicine for sick people, possessed people, and also for offerings to their ancestors. Furthermore, in the Tugu Si Raja Batak, carvings made because the Si Raja Batak seat requires beautiful decoration and their culture to respect the kings
\end{abstract}

Keywords: Connotative, Denotative, Semiotic, Sign, Tugu Si Raja Batak 


\section{INTRODUCTION}

Nowadays, Tugu Si Raja Batak has become a tourist attraction on Samosir Island and is even very popular. The historical and cultural potential of the country is one of the main factors of tourism because 1) it is essential to involve tourists, as knowledge of the historical and cultural heritage is the most substantial incentive for tourists; 2) objects of cultural and historical heritage are essential asset of modern cities, which can make a profit and significantly influence their financial system; 3) It is of great importance in the social sphere, managing seasonal changes and equally spreading tourist sources on the territory; 4) this produces a positive picture of the region, a "branding" of the historical and cultural heritage that used as a useful tool for taking the lead in the tourism arena (Gulnara, 2015). So, the cultural and historical centres not only provide revenue to the city but also give local people the grounds to be proud of their particular heritage and to allow them to share it with visitors.

Historical events that occur in Samosir Island represented by the many historical relics and also cultural nuances of buildings that can interpret events in the past. In this case, the researcher is an exciting study about semiotics perspectives on Tugu Si Raja Batak because Tugu Si Raja Batak has a unique form like Sopo (traditional house) where several statues have historical significance related to the history of the Batak people. Tugu Si Raja Batak is also called Sopo Guru TateaBulan. Thus, the Tugu Si Raja Batak is different from other monuments which are generally soaring, large and tall.

The researcher made the Tugu Si Batak Raja as the object of research because of Si Raja Batak born Batak clans today, including descendants from five sub-ethnic Batak. Then, by knowing the history, signs, and meaning of the Tugu Si Raja Batak, the visitors or tourists can also find out the history of the Batak tribe, especially the young generation of Batak who does not know the hidden meaning of the monument. After making observations at the Tugu Si Raja Batak, the researcher saw that there were signs on the monument related to the history of the Batak people.

Based on the explanation above, the purpose of this research is to find out signs on Tugu Si Raja Batak, to reveal the denotative and connotative meaning as the realizations of the signs, and to describe the reasons for the sign realized.

\section{Semiotic}

According to Peirce, the sign is "something else that stands for something in some respect or capability" (Eco, 1984). The sign has two parts: signifier-signified. A signifier is a physical part; or the tangible thing we see or hear. It is what we perceive. 'Nothing is a sign unless it is interpret as a sign', Peirce said in Chandler (2007).

Umberto Eco (1984) states that signs and symbols are messages; people often communicate by using a sign. Signs can be recognized in the form of words, images, sounds, aromas, tastes, 
actions, or objects, but do not have intrinsic meaning or separate meaning and will become a sign only when people invest into meaning.

\section{Semiotic Theories}

\subsection{Ferdinand de Saussure}

Saussure defined a sign as being composed of a 'signifier' (signifiant) and a 'signified' (signifiê) (Chandler, 2007). Signifier and signified into two elements that make a sign. The Signified and Signifier have a relationship that occurs in the realization as follows the Signifier is realized by Signified or Signified to realize the Signifier. The sign theory put forward by Saussure places more emphasis on specific internal structures for human cognitive thought processes or human thought activities in cognitive thinking in compiling physical (material) or intangible (abstract) signs in their environment, and among them are linguistic sign structures. In a language system that allows them to be able to communicate one each other (Totu, Andreas and Yakin, Halina Sendera M., 2014). For example, when someone smiles, a smile is used as a Signifier. However, it is not confident that a smile has a happy meaning because some people smile. After all, maybe he is crazy, angry, and even insinuating. The signified in the "smile" signifier depends on the situation and people's understanding of the current condition.

\subsection{Charles Sanders Peirce}

The signed model by Peirce is like a model of reality called Triadic. Peirce offered a triadic (three-part) model (Chandler, 2017) consisting of:

1) The representamen $(\mathrm{R})$ : the form which the sign takes (not necessarily material, though usually interpreted as such) - called by some theorists the 'sign vehicle'.

2) The object $(\mathrm{O})$ : one thing on the far side the sign to that it refers (a referent).

3) The interpretant (I): not an interpreter however instead the sense manufactured from the sign.

The sign is that exact physical or abstract entity that may function the "home" of the sign relation. In each terms, a word or a sound can mean is a sign.

\subsection{Roland Barthes}

Roland Barthes developed the idea that there are different orders of meaning (levels of meaning). The first order of signification is denotation: at this point, there is a sign composed of a signifier and a sign. The connotation is the second order of signification that takes the first symbol (signifier and signified sign) as its signifier and adds a sign to it (Chandler, 2017).

In semiotic studies, denotative meanings defined as tangible forms of signs that can be seen directly in the eye. So people can describe the meaning by the characteristics seen by the eye. The connotation is a significant level that explains the relationship between the signifier and the meaning that does not have an explicit meaning. Its meaning is not available on the list of 
dictionaries or has a literary meaning.

Barthes appealed to Hjelmslev to give an account of this critical dimension of meaning. Connotative meanings require knowledge of the social context, and since they require definition and may transcend any intended meaning, they contradict an exact structuralism model of' decoding.' In art, however, denotation is usually foregrounded at the detriment of connotation.

\section{History of Batak}

In folklore, the Batak people came from two people creation of Mulajadi Nabolon (God), called Siraja Ihatmanisia (male), and Siboru Ihatmanisia (woman). Siraja Ihatmanisia has three children, one of whom is in among them the name of Raja Miokmiok. Then Raja Miokmiok's son was named Engbanua and Engbanua had a child named Raja Bonang bonang. Moreover, Raja Bonang bonang has three children named Guru Tantan Debata, Si Asi, and Si Jau. Guru Tantan Debata has a child named Siraja Batak, and Siraja Batak itself has two children named Guru Tatea Bulan and Raja Isumbaon (Sinaga, 2015).

\section{Tugu Si Raja Batak}

Si Raja Batak has many descendants, and today the number of Batak clans can be confirmed. The Batak clans numbered 293 until 2012 (Sinaga, 2015). In general, all the Batak clans made Tugu as a sign of the solidarity and tradition of the origin of the tribe. The same is true of traditional clothing, traditional music, traditional homes, and others. Historical artefacts are items or objects that are particularly guarded by the Batak people as they hold history and memories of the past. Sianipar (2013) said the building of the monument that reflects the relationship between the Pangaranto (nomads) and the brothers in Bona Pasogit (hometown), the rich and the poor, the citizens of the city and the village, the young with the parents of Pomparan (descendant).

There are some relevant studies to support this research that have been made by other researchers. These relevant studies also will be used as references and guidance to help the researcher have a deep understanding of signs so that the author can conduct her study in a right way.

The first by Izzarine Nurdiaz Pramudita, Muhammad Edy Susilo, Christina Rochayanti (2017) the titled is Analysis Of Signs And Meanings In Sariayu Hijab Haircare Advertisements (Semiotic Analysis of Instagram Account @ Sariayuhijab). The result of the research shows that Sariayu Hijab uses a Commodification of Islam that appears in the form of values, attributes, and other signs, as shown in the images. The Islamic interest service can understood by the use of a sacred symbol in the shape of a written advertisement. Other than that, the Commodification of Green Lifestyles is also noticeable in following with their thematic products, such as the use of natural ingredients made up of fruit and vegetables. Sariayu Hijab considers the use of a religious visual sign that considers it necessary to apply to their 
advertisement as a marketing strategy so that the public can be intrigued by buying and wearing products.

The second by Hajjaj (2018) is entitled The Use of Body Language in Jordanian Cartoons: A Semiotic Analysis. In this study, he focused on analyzing the body language used in Jordanian cartoons. This semiotic analysis of the visuals in the 10 Jordanian cartoons showed that the visuals used in Jordanian cartoons convey different connotative meanings. In these videos, clothing used to demonstrate the power relations between characters, the extent of obligation that characters take on, and other information of characters, such as the level of suffering. Gestures used to display the character's personality traits or feelings, while facial expressions used to demonstrate the character's emotional states or attitudes. Posture reflects the actions or attitudes of the characters. In particular, the use of posture was distinct from the other body language features, since the same posture was used to show two opposite meanings in two of the cartoons analyzed.

The third by Ahmad Abdan Syakur, Rusdiawan, Muhammad Sukri (2018) entitled Text of Cigarette Advertisement: A Semiology Study of Roland Barthes. The A-Mild advertisements shown in Mataram city will be studied using the Roland Barthes Semiology approach. The result of this research is the A Mild cigarette advertisement; the concept of myth portrayed through the concepts of style. In the level of myth, the second-tier semi-biological system, this "style" signifier refers to a sign of self-actualization: pleasure, enjoyment, and pertinence.

From those previous studies, it can show that the study of signs on Tugu is still rare. Moreover, the researcher also used Roland Barthes' theory which is proper with this research object. The research is related to culture and history. Therefore, this research used the same theory like previous studies.

\section{RESEARCH METHODOLOGY}

This research used a qualitative approach by Creswell, J. W., \& Creswell, J. D. (2009; 2014) because they considered that the qualitative approach is related to the situation of the individual, and the meaning conveyed by the individual.

The data were the statues and pictures on Tugu Si Raja Batak. The source of data collected from Tugu Si Raja Batak in Sarimarrihit Village, Sianjur Mula-Mula sub-district, Samosir Regency.

The technique of data collection by observation, interview, and documentation. The researcher observes in Tugu Si Raja Batak and used observation sheets to take notes during observation. The interview conducted by face to face, open-ended questions, and unstructured questions with 3 informants they are elders who have lived in Sarimarrihit for many years named Mancur Tua Sagala (63 years old), the head of regency named Mariden Simbolon (53 years old), and Monument Keeper (Penjaga Tugu) named Mitro Limbong (36 years old). And then the researcher takes some photos of 
Tugu Si Raja Batak and informants by using the camera as documentation.

In analyzing the data, descriptive qualitative analysis technique used by the following steps: 1) the researcher transcribes the observation sheet and the results of the interviews with the three informants who have determined above; 2) the researcher read the observation transcript and interview transcript.; 3) during read the transcript, the researcher focused on finding out the name of signs and starting to highlight the name of the signs in transcription.; 4) describe the sign and the realization of the sign using Roland Barthes' sign theory: denotative and connotative. Furthermore, elaborating the meaning of signs on Tugu Si Raja Batak and the reasons for signs realization.

\section{FINDINGS and DISCUSSIONS}

The researcher found twenty-two signs, including human ornaments, animal ornaments, plant ornaments, and carving. Those are Si Raja Batak and Op.Boru Tantan Debata, Lime (Pangir) and Cup, Op. Namartua, Namarsangap, Si Raja Gumeng-gumeleng, Raja Padoha and Si Deak Parmujarak, Op. Raja Isumbaon and Op. Boru Nauli Basa, Silau Raja, Sagala Raja, Tuan Saribu Raja, Guru Tatea Bulan dan Putri Titisan, Dragon, Lion, Horse and Elephant (Gajah Dompak), Banyan Tree (Jajabi), Sisingamangaraja XII and Sisingamangaraja III, Servant (Parhobas and Panuturi), Si Hatti Haumasan, Si Pungga Haumasan, Si Boru Pareme, Si Ratu Biding Laut (Nyi Roro Kidul), Namboru Nattinjo, Si Raja Hatorusan, Limbong Mulana, and Sondi.

Table I.

Signs of Human Ornaments and Meaning

\begin{tabular}{|c|c|c|}
\hline Sings & Denotative Meaning & Connotative Meaning \\
\hline $\begin{array}{l}\text { Si Raja Batak and Op.Boru } \\
\text { Tantan Debata }\end{array}$ & $\begin{array}{l}\text { Man who wear clothes, a } \\
\text { black sash, and a black skirt } \\
\text { and hold a stick. }\end{array}$ & $\begin{array}{l}\text { The bracelet used shows his } \\
\text { might. The king holds the } \\
\text { "Andalu" stick which } \\
\text { signifies a body buffer when } \\
\text { travelling in the forest } \\
\text { (manukkol daging) and uses } \\
\text { the Ulos Toba-Toba which } \\
\text { was an ulos of the Batak } \\
\text { people in ancient times. } \\
\text { Raja also married a } \\
\text { beautiful woman by using } \\
\text { ulos sibolang. }\end{array}$ \\
\hline Raja Uti & $\begin{array}{l}\text { A form of the image of seven } \\
\text { humans who stand in a } \\
\text { forward-facing position that } \\
\text { has limbs such as the nose, } \\
\text { ears, mouth, eyes as the } \\
\text { perfect human. }\end{array}$ & $\begin{array}{l}\text { The king who has seven } \\
\text { forms of magic, seven times } \\
\text { descended to earth, seven } \\
\text { forms, which do not age and } \\
\text { cannot die. The clothes used } \\
\text { are bonang manalu (red- } \\
\text { white-black colour) the } \\
\text { typical colour of the Batak } \\
\text { cosmology }\end{array}$ \\
\hline Si Raja Gumeng-gumeleng & A person who has a small & The king who was born \\
\hline
\end{tabular}




\begin{tabular}{|c|c|c|}
\hline & $\begin{array}{l}\text { body and half of his body } \\
\text { embedded into the cement and } \\
\text { with the body lying face down } \\
\text { while clenching hands }\end{array}$ & $\begin{array}{l}\text { imperfectly but had the } \\
\text { power to realize the requests } \\
\text { of people who come to } \\
\text { convey requests by bringing } \\
\text { the betel, village chicken } \\
\text { eggs, and lime (pangir) to } \\
\text { the king. }\end{array}$ \\
\hline 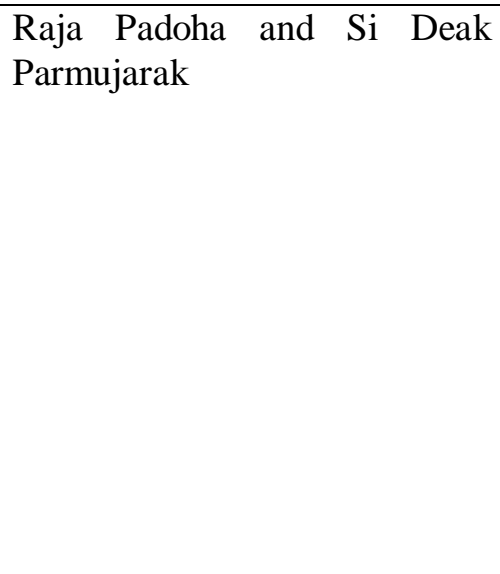 & $\begin{array}{l}\text { Couples who were sitting with } \\
\text { worship or prayer position } \\
\text { while sitting using traditional } \\
\text { attire like in ancient times and } \\
\text { the middle of the picture, } \\
\text { there are the sun, moon, and } \\
\text { stars are illumination objects. }\end{array}$ & $\begin{array}{l}\text { The king who bears the } \\
\text { motto "Dalihan Natolu". } \\
\text { Dalihan Natolu was } \\
\text { consisting of stars, moon, } \\
\text { and sun. Sun means Somba } \\
\text { Marhulahula } \\
\text { /prayer/respect to the wife's } \\
\text { family. The month that } \\
\text { means Elek Marboru } \\
\text { (attitude to persuade/nurture } \\
\text { women), and the sun means } \\
\text { Manat Mardongan Tubu (be } \\
\text { careful of your peers). }\end{array}$ \\
\hline $\begin{array}{l}\text { Op. Raja Isumbaon and Op. } \\
\text { Boru Nauli Basa }\end{array}$ & $\begin{array}{l}\text { A man who holds a stick in his } \\
\text { right hand and also using the } \\
\text { bracelets on both arms. Then, } \\
\text { on his left hand holding a roll } \\
\text { of such a letter. Besides, there } \\
\text { is also a picture of a woman } \\
\text { standing tall beside a man in a } \\
\text { ready and upright position }\end{array}$ & $\begin{array}{l}\text { The king who holds the } \\
\text { source of knowledge in a } \\
\text { book that was once called } \\
\text { the "Buku Lak-lak" in the } \\
\text { left hand and the stick held } \\
\text { by the right hand indicates } \\
\text { that the king has strengths } \\
\text { and strengths. And his wife } \\
\text { uses "ulos sibolang" which } \\
\text { is a historic ulos in the lives } \\
\text { of the Batak people }\end{array}$ \\
\hline Silau Raja & $\begin{array}{l}\text { The man's hair is in braids } \\
\text { with both ends of his hair } \\
\text { drawn forward on the } \\
\text { shoulders. The statue of the } \\
\text { man holds a white cup, and } \\
\text { uses two bracelets on his right } \\
\text { hand and left hand. }\end{array}$ & $\begin{array}{l}\text { The king who has } \\
\text { supernatural powers to cure } \\
\text { diseases of people } \\
\text { traditionally, the Batak } \\
\text { people call it "Datu Bolon". } \\
\text { Braided hair shows the tip } \\
\text { of the Pusuk Buhit. The } \\
\text { king used a cup for the } \\
\text { spices which were taken } \\
\text { directly from the forest of } \\
\text { Pusuk Buhit. }\end{array}$ \\
\hline Tuan Saribu Raja & $\begin{array}{l}\text { A man likes a warlord who } \\
\text { stands proudly with both } \\
\text { hands at the side of the body } \\
\text { and puffs out his chest. } \\
\text { Besides, the man was wearing } \\
\text { a dark black sarong with a } \\
\text { patterned belt. }\end{array}$ & $\begin{array}{l}\text { The king who wears two } \\
\text { bracelets on his arm } \\
\text { signifies a king who has a } \\
\text { wealthy family's line. The } \\
\text { descendants of the king } \\
\text { have supernatural powers } \\
\text { and wealth. Moreover, the } \\
\text { position of both hands } \\
\text { signifies high power. Batak } \\
\text { people used to respect } \\
\text { people who had wealth and } \\
\text { power. }\end{array}$ \\
\hline Guru Tatea Bulan dan Putri & A married couple who stand & The sceptre held by the king \\
\hline
\end{tabular}




\begin{tabular}{|c|c|c|}
\hline Titisan, & $\begin{array}{l}\text { side by side with different } \\
\text { characteristic. The man holds } \\
\text { a long stick in his right hand } \\
\text { and holds a Kris knife } \\
\text { wraspped in a scabbard right } \\
\text { on the left waist. And women } \\
\text { wear long white shirts and } \\
\text { long dark skirts and sashes on } \\
\text { the right shoulder. }\end{array}$ & $\begin{array}{l}\text { is "Tunggkot Panaluan". } \\
\text { Baton is commonly used by } \\
\text { Batak people in traditional } \\
\text { ceremonies to repel } \\
\text { disasters or also bring } \\
\text { disaster. The king was } \\
\text { married to an angel that is } \\
\text { Putri Titisan, who } \\
\text { eventually returns to the sky } \\
\text { after having children- } \\
\text { wearing a white angel that } \\
\text { symbolizes beauty and hair } \\
\text { in a bun meaning a mother. }\end{array}$ \\
\hline $\begin{array}{lll}\text { Servant } & \text { (Parhobas } & \text { and } \\
\text { Panuturi) } & & \end{array}$ & $\begin{array}{l}\text { Three women who are } \\
\text { pounding on a mortar which } \\
\text { has three holes at once in a } \\
\text { parallel position and uses } \\
\text { dark-colored clothing and a } \\
\text { sarong. Then, this picture } \\
\text { shows a woman used a blue } \\
\text { dress with the hairs in a bun } \\
\text { lifting water using a small } \\
\text { bucket from the well. }\end{array}$ & $\begin{array}{l}\text { When having a party, Batak } \\
\text { people usually help each } \\
\text { other to provide banquets at } \\
\text { the party. The servants are } \\
\text { the family of the woman to } \\
\text { collect rice, take water from } \\
\text { the well, and serve the } \\
\text { guests. Usually, Batak } \\
\text { people called as } \\
\text { "Parhobas". The three } \\
\text { women who were pounding } \\
\text { rice indicated that the Batak } \\
\text { women used to clean rice } \\
\text { before using a mortar, and } \\
\text { then they were returned to } \\
\text { produce rice for cooking. } \\
\text { Furthermore, women wear a } \\
\text { sarong as a "lopes" skirt and } \\
\text { wear a sarong as a head } \\
\text { covering or "ampe- } \\
\text { ampe/tali-tali" }\end{array}$ \\
\hline Si Hatti Haumasan & $\begin{array}{l}\text { A woman who is standing } \\
\text { upright using along dress and } \\
\text { with the right shoulder in a } \\
\text { straight down position. }\end{array}$ & $\begin{array}{l}\text { Beautiful woman wearing } \\
\text { traditional Batak Toba } \\
\text { clothes and ulos sibolang. } \\
\text { Ulos Sibolang is an ulos that } \\
\text { is often used by married } \\
\text { people. Besides, the hair in } \\
\text { a bun means that the woman } \\
\text { is married. Batak women } \\
\text { when they are married must } \\
\text { arrange their hair neatly or } \\
\text { in a bun. }\end{array}$ \\
\hline $\begin{array}{l}\text { Sisingamangaraja XII and } \\
\text { Sisingamangaraja III }\end{array}$ & $\begin{array}{l}\text { Two men holding a long stick. } \\
\text { First man hold stick on right } \\
\text { hand, and the second man } \\
\text { hold on the left hand. } \\
\text { Moreover, another hand of } \\
\text { two men placed in front of the } \\
\text { chest as if worshipping. }\end{array}$ & $\begin{array}{l}\text { The two men above are } \\
\text { soldiers who are task with } \\
\text { guarding the Batak people } \\
\text { and holding magic sticks. } \\
\text { The magic baton owned by } \\
\text { the soldier once stabbed in } \\
\text { Bakkara Village, and after } \\
\text { being revoked it produced } \\
\text { river water called "Aek } \\
\text { Sipangolu". The black }\end{array}$ \\
\hline
\end{tabular}




\begin{tabular}{|c|c|c|}
\hline & & $\begin{array}{l}\text { colour used by the man } \\
\text { signifies a strong warrior. }\end{array}$ \\
\hline Si Pungga Haumasan & $\begin{array}{l}\text { A woman who stands upright } \\
\text { in a dark-coloured shirt and } \\
\text { skirt and hair that is neatly } \\
\text { worn }\end{array}$ & $\begin{array}{l}\text { Black clothes worn by } \\
\text { women mean strong } \\
\text { personality, wise, and } \\
\text { decisive. Furthermore, the } \\
\text { hair in a bun shows that the } \\
\text { woman is married. Also, the } \\
\text { woman is in the last row } \\
\text { among her siblings. It can } \\
\text { happened because the } \\
\text { woman was last married, } \\
\text { even though two of the five } \\
\text { siblings were not married. }\end{array}$ \\
\hline Si Boru Pareme & $\begin{array}{l}\text { A woman who wears a dark } \\
\text { dress with a sling on the right } \\
\text { shoulder. The tip of the sash } \\
\text { crossing to the left of her } \\
\text { body. }\end{array}$ & $\begin{array}{l}\text { Batak women in ancient } \\
\text { times when they were } \\
\text { married had to wear long } \\
\text { dresses and skirts, use } \\
\text { sibolang ulos, and hair on a } \\
\text { bun which meant female } \\
\text { characters who were polite } \\
\text { and had offspring. }\end{array}$ \\
\hline $\begin{array}{l}\text { Si Ratu Biding Laut (Nyi Roro } \\
\text { Kidul) }\end{array}$ & $\begin{array}{l}\text { A woman who wears a white } \\
\text { knee-length dress and has her } \\
\text { hair down with her hands } \\
\text { straight forward. The right } \\
\text { foot is behind the body with a } \\
\text { slight bend. }\end{array}$ & $\begin{array}{l}\text { Women's loose hair and } \\
\text { white clothes mean that the } \\
\text { woman is not married. } \\
\text { Moreover, the position of } \\
\text { the hands and feet means } \\
\text { someone who is swimming. } \\
\text { The woman referred to as } \\
\text { Nyi Roro Kidul who lives } \\
\text { on the South Coast (Pantai } \\
\text { Selatan) and is a watchman } \\
\text { on the beach. }\end{array}$ \\
\hline Namboru Nattinjo & $\begin{array}{l}\text { A woman wearing a white } \\
\text { shirt with a kneeling position } \\
\text { and hands placed on both } \\
\text { knees of a woman. }\end{array}$ & $\begin{array}{l}\text { The white shirt worn by the } \\
\text { woman means that the } \\
\text { woman has never been } \\
\text { married. And the position of } \\
\text { the kneeling body shows } \\
\text { that the woman is facing a } \\
\text { king. This woman was the } \\
\text { reason for the "Malau } \\
\text { Island" and became the } \\
\text { ruler of "Tao Simanindo" }\end{array}$ \\
\hline Limbong Mulana & $\begin{array}{l}\text { A man who used a black } \\
\text { shawl and a black skirt, and } \\
\text { holds a snake carved stick } \\
\text { using his left hand. }\end{array}$ & $\begin{array}{l}\text { The snake stick, which is } \\
\text { called "tukkot naimarata" } \\
\text { means the gathering or } \\
\text { "Parsadaan" of the Batak } \\
\text { clans. Meanwhile, the ulos } \\
\text { used by the king are Ulos } \\
\text { Sibolang. Ulos Sibolang is } \\
\text { usually used by Batak } \\
\text { people when grieving. }\end{array}$ \\
\hline Sagala Raja & $\begin{array}{l}\text { A man who used black sash } \\
\text { and a black skirt. Moreover, a } \\
\text { man hold a stick in the right }\end{array}$ & $\begin{array}{l}\text { The clothes that the king } \\
\text { wore were Ulos Toba-Toba } \\
\text { which were the traditional }\end{array}$ \\
\hline
\end{tabular}




\begin{tabular}{|l|l|l|}
\hline & $\begin{array}{l}\text { hand and the position even to } \\
\text { the right side of the body } \\
\text { which has engraving on the tip } \\
\text { of the stick like a human } \\
\text { carving is kneeling. }\end{array}$ & $\begin{array}{l}\text { clothing of the Batak people } \\
\text { in ancient times. } \\
\text { Furthermore, the stick that } \\
\text { held is symbolize of } \\
\text { humanity or "Hajolmaon", } \\
\text { which means how to } \\
\text { maintain human values. }\end{array}$ \\
\hline Si Raja Hatorusan & $\begin{array}{l}\text { A male who stands up using a } \\
\text { black sarong, a white sash, } \\
\text { and a white cap with the } \\
\text { position of his hands like } \\
\text { worshiping. }\end{array}$ & $\begin{array}{l}\text { In the past, not everyone } \\
\text { could pray to Debata } \\
\text { Mulajadi Nabolon, so it was } \\
\text { Si Raja Hatorusan who } \\
\text { delivered all the people's } \\
\text { requests. }\end{array}$ \\
\hline
\end{tabular}

From the results above, it can concluded that human ornaments because human ornaments that appear on Tugu Si Raja Batak were descended from Si Raja Batak and also things related to the life history of Si Raja Batak.

Table II.

Signs of Animal Ornaments and Meaning

\begin{tabular}{|l|l|l|}
\hline Signs & Denotative Meaning & Connotative Meaning \\
\hline $\begin{array}{l}\text { Dragon, Lion, Horse, and } \\
\text { Elephant (Gajah Dompak) }\end{array}$ & $\begin{array}{l}\text { Animals that look like real } \\
\text { animals that have eyes, legs, } \\
\text { and bodies except for dragons } \\
\text { which have a long body shape } \\
\text { and forked tails. }\end{array}$ & $\begin{array}{l}\text { These animals are used by } \\
\text { descendants of Si Raja Batak } \\
\text { if go to another place or do } \\
\text { work in the forest to look for } \\
\text { food. }\end{array}$ \\
\hline
\end{tabular}

From the results above, it can concluded that the animal ornaments made related to the tradition of Batak people to used animals as transportation and when they work in the field and took food in the forest.

Table III.

Signs of Plants Ornaments and Meaning

\begin{tabular}{|c|c|c|}
\hline Signs & Denotative Meaning & Connotative Meaning \\
\hline $\begin{array}{l}\text { Banyan Tree (Jajabi) and } \\
\text { Lime }\end{array}$ & $\begin{array}{l}\text { The sign above is a tree that is } \\
\text { generally called a banyan tree } \\
\text { with very lush green leaves } \\
\text { and dark brown stems Lime } \\
\text { (Pangir) which is usually use } \\
\text { for food seasoning. }\end{array}$ & $\begin{array}{l}\text { Banyan Tree which means } \\
\text { shelter or "panggomgom". } \\
\text { Batak people are often called } \\
\text { Parbaringin people who have } \\
\text { complete descent (saur } \\
\text { matua). Lime has a meaning } \\
\text { as a body cleansing agent } \\
\text { (traditional self-preparation) }\end{array}$ \\
\hline
\end{tabular}

From the results above, it can concluded that the plant ornaments appear because of the custom of the Batak tribe with traditional treatment. Moreover, the sign shows the tradition of the Batak tribe to respect their ancestors.

Table IV.

Sign of Carve and Meaning

\begin{tabular}{|l|l|l|}
\hline Sign & Denotative Meaning & Connotative Meaning \\
\hline Sondi & The sign above is a seat that & The seats were use by kings in \\
\hline
\end{tabular}




\begin{tabular}{|l|l|l|}
\hline & $\begin{array}{l}\text { has carved buffalo heads with } \\
\text { red, white, and black forked } \\
\text { horns. }\end{array}$ & $\begin{array}{l}\text { ancient times. And red, white, } \\
\text { and black gorga mean banua } \\
\text { ginjang (sky), banua tonga } \\
\text { (earth), and banua toru } \\
\text { (afterlife). Carving (gorga) is } \\
\text { a typical ornament for the } \\
\text { Batak people. }\end{array}$ \\
\hline
\end{tabular}

From the results above, it can concluded that the carving made because the seat of Si Raja Batak requires beautiful decoration and the carving made as to the culture of the Batak ethnic to respect the kings.

\section{CONCLUSIONS}

There were twenty-two signs found on Tugu Si Raja Batak in four forms, they are human ornaments consist of Si Raja Batak and Op. Boru Tantan Debata, Raja Uti, Si Raja Gumenggumeleng, Raja Padoha, and Si Deak Parmujarak, Op. Raja Isumbaon and Op. Boru Nauli Basa, Silau Raja, Sagala Raja, Tuan Saribu Raja, Guru Tatea Bulan dan Putri Titisan,

Sisingamangaraja XII and Sisingamangaraja III, Servant (Parhobas and Panuturi), Si Hatti Haumasan, Si Pungga Haumasan, Si Boru Pareme, Si Ratu Biding Laut (Nyi Roro Kidul), Namboru Nattinjo, Si Raja Hatorusan, and Limbong Mulana. Animal ornaments consist of Dragon, Lion, Horse, and Elephant (Gajah Dompak), plant ornaments consist of Banyan Tree (Jajabi) and Lime (Pangir), and carving that is Sondi.

The meaning realized into two terms, namely denotative meaning and connotative meaning. First, denotative meaning of human ornaments men and women with each characteristic, animal ornaments mean the animals with a full-body, plant ornaments mean the tree with thick leaves and green lime, and the last carving means the seat or bed of kings that consisting of three colours; red, white, and black. Second, the connotative meaning of human ornaments conveys men and women show descendants of Si Raja Batak and characteristics of Batak ethnic, animal ornaments mean the transportation of Batak people and help them in the field/forest, plant ornaments shelter/ "panggomgom" and traditional treatment of the Batak tribe, and carving: a beautiful decoration for the seat of kings.

The realization of human ornaments because human ornaments that appear on Tugu Si Raja Batak were descended from Si Raja Batak and also things related to the life history of Si Raja Batak. Animal ornaments made related to the tradition of Batak people to used animals as transportation and when they worked in the field and took food in the forest. Plant ornaments appear because of the custom of the Batak tribe with traditional treatment. Moreover, the sign shows the tradition of the Batak tribe to respect their ancestors. Moreover, carving made because the seat of Si Raja Batak requires beautiful decoration and the carving made as to the culture of the Batak ethnic to respect the kings. 


\section{SUGGESTIONS}

The researcher suggests that by understanding the theory, it is essential to help the reader to distinguish and look for the true meaning of signs, because sometimes in perception and culture will significantly make the meaning obtained is very different. Moreover, the researcher hopes that the young generation can keep Tugu Si Raja Batak and understand the meaning of Tugu Si Raja Batak. Especially for the Batak young generation, they have to memorize the norm of Batak culture.

\section{REFERENCES}

Ahmad Abdan Syakur, Rusdiawan, Muhammad Sukri, (2018). Text of Cigarette Advertisement: A Semiology Study of Roland Barthes. International Journal of Linguistics, Literature, and Culture, 4(3), 72-79. Retrieved from https://sloap.org/journals/index.php/ijllc/article/view/182

Chandler, D. (2007). Semiotics: The Basic. New York: Routledge.

Chandler, D. (2017). Semiotics: The Basic. New York.

Creswell, J. W. (2009; 2018). Research Design: Qualitative, Quantitative, and Mixed Methods Approaches. SAGE Publications, Inc.

Eco, U. (1984). Semiotics and Philosophy of Language. MACMILLAN.

Gulnara Ismagilova, Lenar Safiullin, Ilshat Gafurov, (2015). Using Historical Heritage as a factor in tourism development. Procedia-Science and Behavioral Science, 157-162.

Hajjaj, D. (2018). The Use of Body Language in Jordanian Cartoons: A Semiotic Analysis. Advances in Language and Literary Studies, 9(3), 19-24.

Izzarine Nurdiaz Pramudita, Muhammad Edy Susilo, Christina Rochayanti, (2017). Analysis Of Signs And Meanings In Sariayu Hijab Haircare Advertisements (Semiotic Analysis of Instagram Account. The Indonesian Journal of Communication Studies, 10(2), 94-107.

Sianipar, B. (2013). Horas, Dari Batak Untuk Indonesia. Jakarta: Rumah Indonesia. Sinaga, R. (2015). Silsilsh Marga Marga Batak. Dian Utama dan Mitra Medan. 